\title{
Testing the potential of pollen assemblages to capture composition, diversity and ecological gradients of surrounding vegetation in two biogeographical regions of southeastern Europe
}

\author{
Maria Papadopoulou ${ }^{1} \cdot$ Ioannis Tsiripidis ${ }^{2}$ (D) Sampson Panajiotidis ${ }^{3}$ (D) $\cdot$ Georgios Fotiadis $^{4}$ (D) \\ Daniel Veres $^{5}$ (1) - Enikö Magyari ${ }^{6,7}$ (D) Marc Bormann ${ }^{1} \cdot$ Sonia Fontana ${ }^{8} \cdot$ Lyudmila Shumilovskikh $^{9,10}$ (1) \\ Konstantinos Panagiotopoulos ${ }^{11}$ (1) $\cdot$ Frank Schäbitz $^{1}$ (]) Thomas Giesecke ${ }^{12}$ (I)
}

Received: 27 April 2020 / Accepted: 9 March 2021 / Published online: 18 May 2021

(c) The Author(s) 2021

\begin{abstract}
Due to the complex relationship between pollen and vegetation, it is not yet clear how pollen diagrams may be interpreted with respect to changes in floristic diversity and only a few studies have hitherto investigated this problem. We compare pollen assemblages from moss samples in two southeastern European forests with the surrounding vegetation to investigate (a) their compositional similarity, (b) the association between their diversity characteristics in both terms of richness and evenness, and (c) the correspondence of the main ecological gradients that can be revealed by them. Two biogeographical regions with different vegetation characteristics, the Pieria mountains (north central Greece) and the slopes of Ciomadul volcano (eastern Romania), were chosen as divergent examples of floristic regions, vegetation structure and landscape openness. Pollen assemblages are efficient in capturing the presence or absence, rather than the abundance in distribution of plants in the surrounding area and this bias increases along with landscape openness and vegetation diversity, which is higher in the Pieria mountains. Pollen assemblages and vegetation correlate better in terms of richness, that is, low order diversity indices. Relatively high correlation, in terms of evenness, could be potentially found in homogenous and species poor ecosystems as for Ciomadul. Composition and diversity of woody, rather than herb, vegetation is better reflected in pollen assemblages of both areas, especially for Pieria where a direct comparison of the two components was feasible, although this depends on the species-specific pollen production and dispersal, the openness of landscape and the overall diversity of vegetation. Gradients revealed by pollen assemblages are highly and significantly correlated with those existing in vegetation. Pollen assemblages may represent the vegetation well in terms of composition, diversity (mainly richness) and ecological gradients, but this potential depends on land use, vegetation structure, biogeographical factors and plant life forms.
\end{abstract}

Keywords Diversity $\cdot$ Hill's numbers $\cdot$ Pollen assemblages $\cdot$ Vegetation $\cdot$ Richness $\cdot$ Evenness

\section{Introduction}

Palaeoecological studies can offer insights into past changes of vegetation diversity driven by climate or human impact (Odgaard 1999; Berglund et al. 2008; Colombaroli and Tinner 2013; Giesecke et al. 2019). A recent review (Birks et al. 2016) strongly supports this view and discusses the need for exploring modern pollen-vegetation relationships in terms of

Communicated by W. Tinner.

Sampson Panajiotidis pansamp@ for.auth.gr

Extended author information available on the last page of the article diversity. Several studies (for example, Meltsov et al. 2011; Matthias et al. 2015; Felde et al. 2016; Reitalu et al. 2019) have provided evidence for statistically significant relationships between pollen and plant diversity; however, Odgaard (2008) cautions that attempts to reconstruct components of past plant diversity are potentially biased. These biases are well known and include taxon-specific pollen production and dispersion properties, low pollen taxonomic resolution and lack of a fixed pollen source area (Giesecke et al. 2014). Studies comparing the modern relationship also need to consider biases introduced by sampling design and the data used in the analyses (Birks et al. 2016).

Diversity is traditionally assessed through taxa richness (number of taxa) and evenness (abundance of taxa) (Gotelli 
and Chao 2013). Palynological richness, the number of pollen types encountered in a sample, increases with the number of pollen grains examined or counted (Rull 1987) and therefore it needs to be compared at a standardized sum (Birks and Line 1992). Odgaard (1999) demonstrated how the encounter of pollen types declines for samples with a standardized pollen sum, when the vegetation changes from low to high pollen producers. It should be theoretically possible to reduce this bias by adjusting for pollen production and dispersal. However, Matthias et al. (2015) did not find an improvement with adjusted pollen proportions, while Felde et al. (2016) obtained a better fit between pollen and floristic plant richness when applying simple correction factors. Given a well dated sediment accumulation, which is usually the case for varved sediments, van der Knaap (2009) demonstrated that it is possible to circumvent the problem of differential pollen dispersal and deposition by estimating the number of different pollen types deposited per unit of sediment and time. Other biases, like low pollen taxonomic resolution, may not be resolved and Odgaard $(2001,2008)$ therefore suggested that investigating the dynamics of pollen and vegetation evenness might be more rewarding. Matthias et al. (2015) compared different diversity indices and found that the Shannon index compared best with the number of different vegetation types, while other studies found relationships for richness (Felde et al. 2016). The limited number of modern studies comparing pollen and vegetation diversity does not yet provide conclusive interpretations of pollen diversity, evenness and richness.

Hill's numbers (Hill 1973) constitute a useful approach to diversity partitioning as they can be calculated with different weights given to the richness and evenness components of diversity and they are very effective in comparing diversity between different assemblages (Ellison 2010; Birks et al. 2016). In addition to Hill's numbers, Birks et al. (2016) suggest that studies exploring modern diversity patterns of pollen and vegetation should also include multivariate approaches, such as co-correspondence analysis, that allow the simultaneous assessment of the co-variation of datasets derived from identical sampling sites. Compositional similarity between pollen assemblages and surrounding vegetation constitutes a basic prerequisite for reliable interpretation of palaeoecological data (Birks and Birks 1980). Many studies investigated the similarity between pollen assemblages and floristic composition of surrounding vegetation types (for example, Hjelle 1999; Fall 2012; Felde et al. 2014). In most cases, such studies showed that pollen assemblages can reveal different vegetation types, although the pollen biases mentioned above may blur this potential. Appropriate sampling design as far as scale, sampled area and measurement methods are concerned, is essential to acquire reliable data and reveal meaningful relationships (Felde et al. 2016; Birks et al. 2016). Ordination analysis can further help to assess whether modern pollen assemblages correspond to the main vegetation gradients (Legendre and Birks 2012).

There is a lack of integrated studies of compositional similarity and diversity of pollen and surrounding vegetation for south-east Europe, where most of the palaeoecological studies have been carried out in mountainous areas such as the Pieria mountains (Gerasimidis and Panajiotidis 2010) and Mohoş (Tanţău et al. 2003). Feurdean et al. (2013), in a comparative study of cores collected in the Romanian Carpathians, point out that land use and landscape openness influence the elevational patterns of palynological richness. Moreover, the site Mohoş (Ciomadul, Romanian eastern Carpathians), situated in closed beech forests of low vegetation diversity, showed low palynological richness, a feature prominent over the last century due to the intensification of land use (mainly forestry plantations) on a regional scale.

In this study, we compare pollen assemblages with vegetation plots collected from two areas, the Pieria mountains in north-central Greece and the Ciomadul lava-dome complex in the Romanian Eastern Carpathians. The former is a semi-open forested mountain in the Mediterranean region, with high landscape diversity that leads to a greater floristic richness, while the latter is an extensive dense Fagus dominated forest with a species poor understory vegetation in the continental biogeographical region. In Ciomadul dense forests are surrounded by large forestry plantations and open grazed meadows. In the Pieria mountains farming is restricted to low altitudes, with grazing in scrub. Beech forests are subjected to felling, with variously opened stands.

We sampled the modern vegetation of vascular taxa within the altitudinal range of beech forests in both areas, in circles of 10 and $100 \mathrm{~m}$ radius around moss cushions from which the modern pollen deposition was analysed. In this comparison, we focused on the following features: (a) compositional similarity, to assess the degree in which vegetation composition is represented by pollen assemblages; (b) similarity of diversity (both richness and evenness components), by exploring different orders of Hill's numbers, and the potential of pollen assemblages to capture vegetation diversity; and (c) correspondence of gradients revealed by pollen and vegetation data.

Specifically, we address the following questions:

1. To what extent the herb and woody components of pollen assemblages in moss cushions resemble corresponding components in the surrounding vegetation sampled at different spatial scales of 10 and $100 \mathrm{~m}$ radii?

2. Does the pollen type diversity represent species diversity in the vegetation, and which component of diversity (richness or evenness) exhibits the strongest relationship between pollen assemblages and vegetation?

3. Is there any correspondence between the main gradients revealed by pollen assemblages and vegetation? 
Differences in terms of landscape openness, land use and vegetation structure between the two regions are considered in an attempt to interpret compositional similarity and diversity correlation results.

\section{Studied regions}

The Pieria mountains (up to 2,104 m) are situated in northern central Greece, extending in a north-northeast to southsouthwest direction, thus having eastern and western slopes (Fig. 1). There is an altitudinally stratified vegetation composed of low-altitude thermophilous oak woodlands and scrub with Quercus coccifera, $Q$. frainetto and $Q$. pubescens, mid-altitude (800-1,700 m) semi-open beech forests with Abies borisii-regis stands and high altitude pine woodlands of Pinus sylvestris and P. nigra. Apart from the major vegetation types mentioned above, small stands of Carpinus orientalis, C. betulus, Ostrya carpinifolia, Corylus avellana and Juniperus spp. are encountered (Gerasimidis et al. 2006). The eastern slopes of the massif are exposed to rainbearing winds from the Aegean Sea. Annual precipitation ranges between $900 \mathrm{~mm}$ in the lower and ca. 1,200 $\mathrm{mm}$ in the upper beech forests, with its maximum during winter and its minimum in summer (Katsavouni et al. 2014).
The Ciomadul lava dome complex (up to 1,301 m), situated in central Romania, belongs to the Inner Carpathian volcanic chain, and is covered mainly by mature, dense forest of Fagus sylvatica (beech) and Picea abies (spruce) (Fig. 1). However, trees and shrubs such as Carpinus betulus, Betula pubescens, Corylus avellana, Alnus glutinosa, Abies alba and Pinus sylvestris are also found in the area. The zonal vegetation of the area belongs to the Symphyto cordati-Fagetum vegetation association (Coldea 1991). The climate is temperate-montane with an annual precipitation reaching above $1,000 \mathrm{~mm}$ and presenting, in contrast to the Pieria mountains, a maximum during summer and a minimum in winter.

\section{Material and methods}

\section{Moss cushion sampling}

Moss cushions were sampled during the summers of 2011 (Pieria mountains, $22^{\circ} 13^{\circ} 00^{\prime \prime}$ to $22^{\circ} 16^{\circ} 30^{\prime \prime} \mathrm{E}$ and $40^{\circ} 13^{\prime} 30^{\prime \prime}$ to $40^{\circ} 21^{\prime} 30^{\prime \prime} \mathrm{N}$ ) and 2014 (Ciomadul, $25^{\circ} 51^{\prime} 00^{\prime \prime}$ to $25^{\circ} 56^{\circ} 00^{\prime \prime} \mathrm{E}$ and $46^{\circ} 05^{\circ} 00^{\prime \prime}$ to $\left.46^{\circ} 10^{\circ} 00^{\prime \prime} \mathrm{N}\right)$. Aerial photos with a scale 1:10,000 were used to select the sampling points. To capture most of the landscape diversity in the Pieria mountains, sampling sites were selected in the oak woodland/beech forest and beech/pine forest transition
Fig. 1 Location of the two study areas. On right above, Ciomadul, Romania; right below, Pieria mountains, Greece (modified after Google maps)

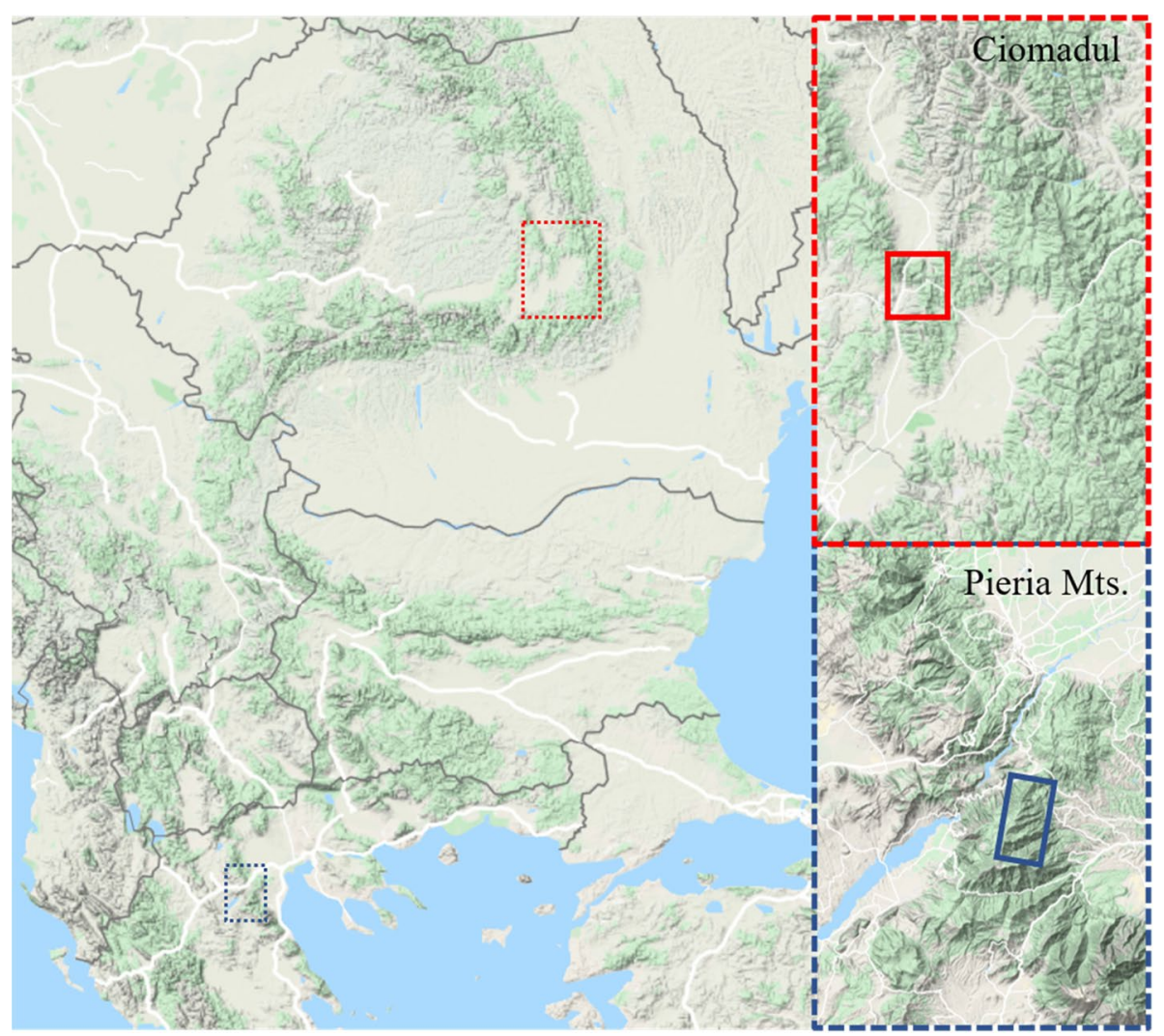


zones, including sites with mixed beech/fir stands. Within the beech matrix at Ciomadul, sites with differing abundances of major trees (Fagus, Picea, Betula, Alnus, Pinus) were chosen in order to capture most of the landscape diversity. A $5 \mathrm{~cm}$ diameter circular moss cushion was collected from each vegetation sampling location. Moss cushions were collected from an altitudinal range of ca. 850-1,600 $\mathrm{m}$ in Pieria and 700-1,310 $\mathrm{m}$ in Ciomadul. Fourteen sampling sites were selected in Pieria and 18 in Ciomadul (Fig. 2).

\section{Vegetation sampling and mapping}

In both areas the protocol of Bunting et al. (2013) was adopted, with some modification for the recording of herb vegetation in the Pieria mountains to help capture the higher heterogeneity that characterizes mountainous Mediterranean vegetation. The protocol combines different approaches for the various vegetation layers (tree/ shrub and herb). The floristic composition of the vascular plants in the herb layer was recorded within a $10 \mathrm{~m}$ radius around each sampling point. This distance is considered representative of the relevant pollen source area of many herbaceous taxa (Hjelle 1997; Bunting 2003; Bunting et al. 2013), but it may vary in size depending on the pollen taxon (Shaw and Whyte 2020). The herb cover was estimated by using 33 quadrats of $0.25 \mathrm{~m}^{2}$ in the Pieria mountains and 21 quadrats of $1 \mathrm{~m}^{2}$ in Ciomadul. The quadrats in both study areas were placed within the $10 \mathrm{~m}$ radius in eight different directions, north, northeast, east etc., and at different distances from the sampled moss cushion. The canopy cover of woody taxa, which are generally high pollen producers, was estimated in $10 \mathrm{~m}$ concentric rings within the range 10-100 $\mathrm{m}$ from each moss cushion. Similarly, the canopy cover of woody taxa present in the $0-10 \mathrm{~m}$ radius was estimated in concentric rings of $1 \mathrm{~m}$. In Pieria, open tree canopy within $10 \mathrm{~m}$ radius was more than $50 \%$ of the respective total area in half the sampling points, with minimum and maximum values of 6.6 and $100 \%$ of total area respectively. In Ciomadul open canopy within a $10 \mathrm{~m}$ radius was less than $10 \%$ of the total area
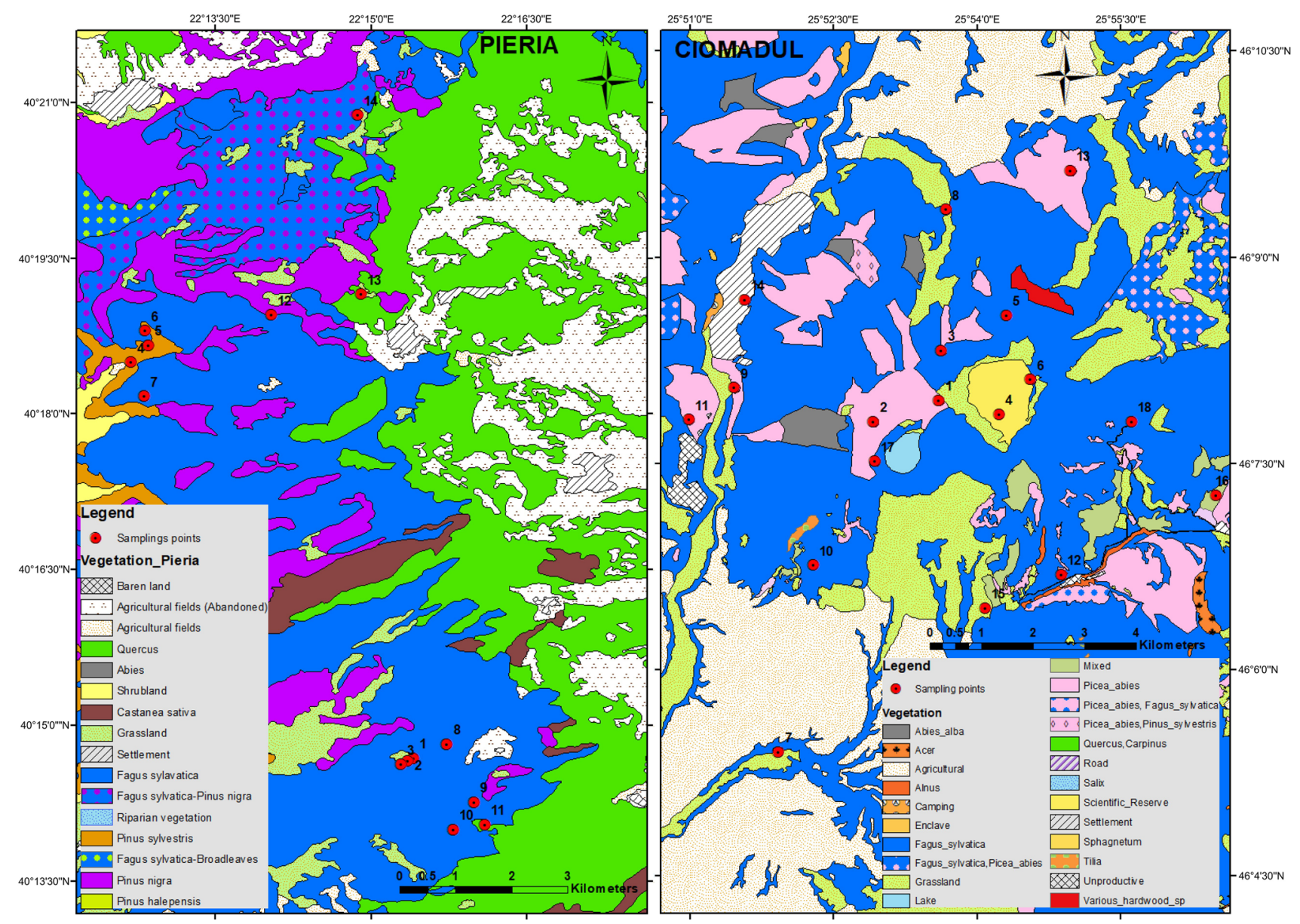

Fig. 2 Vegetation units and sampling points. Left, Pieria mountains; right, Ciomadul. Circles represent the 10 and $100 \mathrm{~m}$ radius sampled vegetation areas 
in two thirds of the sampling points, while minimum and maximum values reached 1 and $76 \%$ respectively.

\section{Pollen analysis and data preparation}

The moss polsters were processed following Hicks et al. (1996), washing the contents of the moss sample into a cellulose filter paper that is then acetolysed. Samples from the Pieria mountains were prepared at the laboratory of Forest Botany-Geobotany at the Aristotle University of Thessaloniki, Greece, while those of Ciomadul at the laboratory of the Institute of Geography and Education, University of Cologne, Germany. A light microscope with $400 \times$ magnification was used to identify the pollen and spores. Pollen and spore identification was based on published keys and atlases (Reille 1992, 1995; Chester and Raine 2001; Beug 2004) as well as on reference material held at both laboratories. A minimum of 500 arboreal pollen grains were counted for each sample (Hicks et al. 1996). Throughout the text the term 'herbs' refers to both pollen of angiosperms and spores of vascular cryptogams.

Vascular plant taxa were identified to species or subspecies level following Flora Europaea (Tutin et al. 1968, 1993). Identified taxa were transformed to pollen and spore equivalents with taxa belonging to the same pollen/spore type, based on Beug (2004) and their cover abundances were merged to the corresponding pollen equivalent assemblages (Tichý et al. 2011). To explore different components of the pollen signal we created different subsets of Pollen Type assemblages (PTas) and Pollen-Equivalent assemblages (PEas) using two sampling distances (10 and $100 \mathrm{~m})$ as well as different combinations of plant life form (herbs; trees + shrubs; all terrestrial vascular plants) as constraints. Herb data sets for Ciomadul were not analysed, as some of the PTas had very low herb pollen counts with less than 20 pollen grains (ESM 1 Table 6). Thus, four different combinations were evaluated:

allPV: all pollen and spore PEas of vegetation (allV) vs. pollen and spore PTas (allP), only for the $10 \mathrm{~m}$ radius plots where all plant life forms were recorded;

herbPV: herb PEas of vegetation plots (herbV) within 10 $m$ radius vs. herb $\mathrm{PTas}$ (herbP);

woodPV: woody PEas of vegetation (wooV) within $10 \mathrm{~m}$ radius vs. woody PTas (wooP);

woodPV-100: woody PEas of vegetation (wooV-100) within $100 \mathrm{~m}$ radius vs. woody PTas (wooP).

\section{Data analysis}

To eliminate the bias introduced by the different sizes of the pollen counts within each data set, we resampled each PTa to the minimum pollen count recorded in each site, following
Felde et al. (2016), although for each PTa we resampled 100 times, since pollen count size differences were relatively small. Bray-Curtis coefficients were calculated for each PEa and all the 100 corresponding PTas resulting from resampling. The average and standard deviations were calculated. Similarly, for each Pta, an average value of diversity for each order of diversity (Hill's numbers), was calculated from all the 100 pollen samples derived from resampling (Hill 1973; Chao et al. 2014). Hill's numbers were also calculated for each PEa. The advantage of Hill's numbers is that they produce different indices that represent both species richness and evenness by giving different weights to the two components (Hill 1973; Chao et al. 2014). The weight of the abovementioned components of diversity is tuned by a parameter, called the "order" of diversity and is symbolized by the letter $\mathrm{q}$ (Jost 2006). We used the following q values: 0, 0.25, 0.5, $1,2,4,8,16,32,64$ and $\infty$.

Calculating the dissimilarity, we explored how well each PTa set represented the corresponding PEa set. Three calculations of Bray-Curtis similarity coefficient were made using the following data: 1 , presence or absence of pollen types/pollen equivalents; 2 , untransformed percentage cover (pollen equivalents)/frequencies (pollen types); and 3 , square root transformed and normalized percentages of pollen types or pollen equivalents. We compared the Hill's numbers between each combination of vegetation and pollen datasets using Spearman's rank correlation coefficient (Spearman 1904). For each PTa and its Hill's numbers of a specific order, q correlations were calculated with Hill's numbers of its corresponding PEa set for the same and all other selected orders of q. This pattern of calculations was applied to all Hill's numbers derived from the selected $q$ orders for each PTa set. Hill's numbers of different q values are expected to present weaker and perhaps insignificant correlations, because of the different weight given through the different $q$ values to abundances and to common and rare taxa (Jost 2006). However, a different trend cannot be precluded, considering that Hill's numbers were calculated for different entities, the species for the vegetation samples, and pollen types for the pollen assemblages. Moreover, presence of pollen types in a sample, contrary to their vegetation equivalents, is a much more biased and stochastic procedure in terms of abundance and richness, a fact that merits exploration for potential correlational patterns between diversities of different q orders.

To further explore the similarity between pollen assemblages and vegetation plots, we performed non-metric multidimensional scaling (NMDS) using the different data sets. Percentages of pollen types and equivalents were square root transformed and normalized before NMDS analysis. BrayCurtis distance between vegetation plots or pollen assemblages was used as a distance measure. In order to investigate the correlation between the ordination diagrams of 
corresponding PEa/PTa sets, we applied a permutation test based on a Procrustes statistic (PROTEST) (Jackson 1994; Peres-Neto and Jackson 2001). PROTEST compares two ordinations using symmetric Procrustes analysis (Oksanen 2015) and it results in the correlation $r$ between the two ordinations, its significance on the basis of a permutation test and the symmetric Procrustes residual between configurations after optimal fit $\left(\mathrm{m}^{2}\right)$, which is low when there is a close match between ordinations (Peres-Neto and Jackson 2001).

Bray-Curtis similarity coefficients, Hill's numbers, NMDS and PROTEST were done with vegan v. 2.2.1 (Oksanen et al. 2013) in R v. 3.1 .2 (R Core Team 2014). Spearman's correlation coefficients were calculated using SPSS (IBM 2012). Diagrams were drawn using Origin Pro v. 7.5 SR6 (OriginLab 1991-2006).

\section{Results}

\section{Plant taxa and pollen types recorded in vegetation and moss cushions}

In the Pieria mountains, 264 plant taxa were identified in the sampling plots around the moss cushions, a very high number considering that the total sampled area was about $40 \%$ of that sampled in Ciomadul. These taxa were assigned to 111 pollen and spore equivalents, of which 95 were herbaceous (85.6\%), 14 woody plants (12.6\%) and two ferns. A total of 102 pollen and spore types were recorded in the corresponding pollen assemblages of which 65 belong to herbaceous taxa (63.7\%), 31 to woody taxa (30.4\%) and six to ferns. A total of 50 pollen types (45\%), of which 26 herbaceous ( $40 \%$ of all herbs) and 20 woody types ( $64.5 \%$ of all trees and shrubs), were not recorded in the sampled vegetation.

In Ciomadul only 134 plant taxa were identified in the vegetation plots. These were assigned to 82 pollen and spore equivalents, of which 66 were herbaceous $(80.5 \%)$, 13 woody taxa $(15.9 \%)$ and three ferns $(3.7 \%)$. A total of 37 pollen and spore types were recorded in the corresponding pollen assemblages of which 19 belong to herbaceous taxa (51.4\%), 15 to woody $(40.5 \%)$ and three to ferns $(8.1 \%)$. A total of 12 types (32.4\%), comprising seven herbaceous (36.8\% of all herbs) and four woody types (26.7\% of all trees and shrubs), were not recorded in the sampled vegetation.

For the Pieria mountains, about 41\% (39/95) of the herb equivalents present in the plots were also recorded in the pollen assemblages, but on the contrary, for Ciomadul only $18.2 \%(12 / 66)$ of the herbaceous equivalents were also recorded. In both areas, nearly all woody equivalents present in the sampled vegetation were also recorded in the pollen assemblages, 13 out of 14 or $92.85 \%$ for Pieria and 11 out of 13 or $84.6 \%$ for Ciomadul. Most pollen samples from Pieria are characterised by very low pollen counts of Fagus and more than half of the samples have values around or less than 5\% (ESM 1 Table 3), while for Ciomadul the situation is reversed and more than half of the samples have values over 20\% (ESM 1 Table 6).

\section{Similarity between vegetation plots and pollen assemblages}

Presence/absence based similarity coefficients were always higher (more similar) than those based on abundance of pollen types and pollen equivalents (Table 1). Similarity coefficients of the square root transformed percentage data were intermediate or closer to those of presence/absence data (Table 1). For both areas, the Bray-Curtis similarity coefficients of presence/absence and frequency data of PEas and their corresponding PTas are highly variable for most cases (Fig. 3). The largest bias, in terms of similarity, between presence/absence and frequency data sets is observed for Pieria (Fig. 3). For both areas, PTas and PEas representing woody components within $100 \mathrm{~m}$ were the most similar. For Pieria, the woody PTa/PEa sets were less similar than the corresponding sets of total floristic composition for the $10 \mathrm{~m}$ plots. In contrast, for Ciomadul the pollen assemblages and presence/absence records of the woody component from the vegetation plots within $10 \mathrm{~m}$ were much more similar than

Table 1 Median and standard deviation of the Bray-Curtis similarity coefficient values between different vegetation PEas and their corresponding Ptas for Pieria and Ciomadul. allPV, $10 \mathrm{~m}$ total component; wooPV, 10 m woody component; wooPV-100, 100 m woody component; herbPV, $10 \mathrm{~m}$ herb component

\begin{tabular}{llllll}
\hline Data set & \multicolumn{2}{l}{ Pieria Mts. } & & \multicolumn{2}{l}{ Ciomadul } \\
\cline { 2 - 3 } & Median & SD & & Median & SD \\
\hline allPV $^{\mathrm{a}}$ & 0.294 & 0.066 & 0.310 & 0.084 \\
allPV $^{\mathrm{b}}$ & 0.245 & 0.056 & 0.324 & 0.066 \\
allPV $^{\mathrm{c}}$ & 0.14 & 0.073 & & 0.269 & 0.066 \\
wooPV $^{\mathrm{a}}$ & 0.255 & 0.114 & 0.524 & 0.181 \\
wooPV $^{\mathrm{b}}$ & 0.225 & 0.105 & 0.397 & 0.101 \\
wooPV $^{\mathrm{c}}$ & 0.097 & 0.09 & 0.283 & 0.075 \\
wooPV-100 $^{\mathrm{a}}$ & 0.433 & 0.057 & 0.626 & 0.134 \\
wooPV-100 $^{\mathrm{b}}$ & 0.352 & 0.075 & 0.482 & 0.082 \\
wooPV-100 $^{\mathrm{c}}$ & 0.167 & 0.055 & 0.331 & 0.037 \\
herbPV $^{\mathrm{a}}$ & 0.264 & 0.082 & & \\
herbPV $^{\mathrm{b}}$ & 0.176 & 0.066 & & \\
herbPV $^{\mathrm{c}}$ & 0.091 & 0.055 & & \\
\hline
\end{tabular}

${ }^{\mathrm{a}}$ Based on presence-absence data

${ }^{\mathrm{b}}$ Based on the untransformed cover values (for vegetation plots) and pollen frequencies

${ }^{\mathrm{c}}$ Based on power transformed cover values 

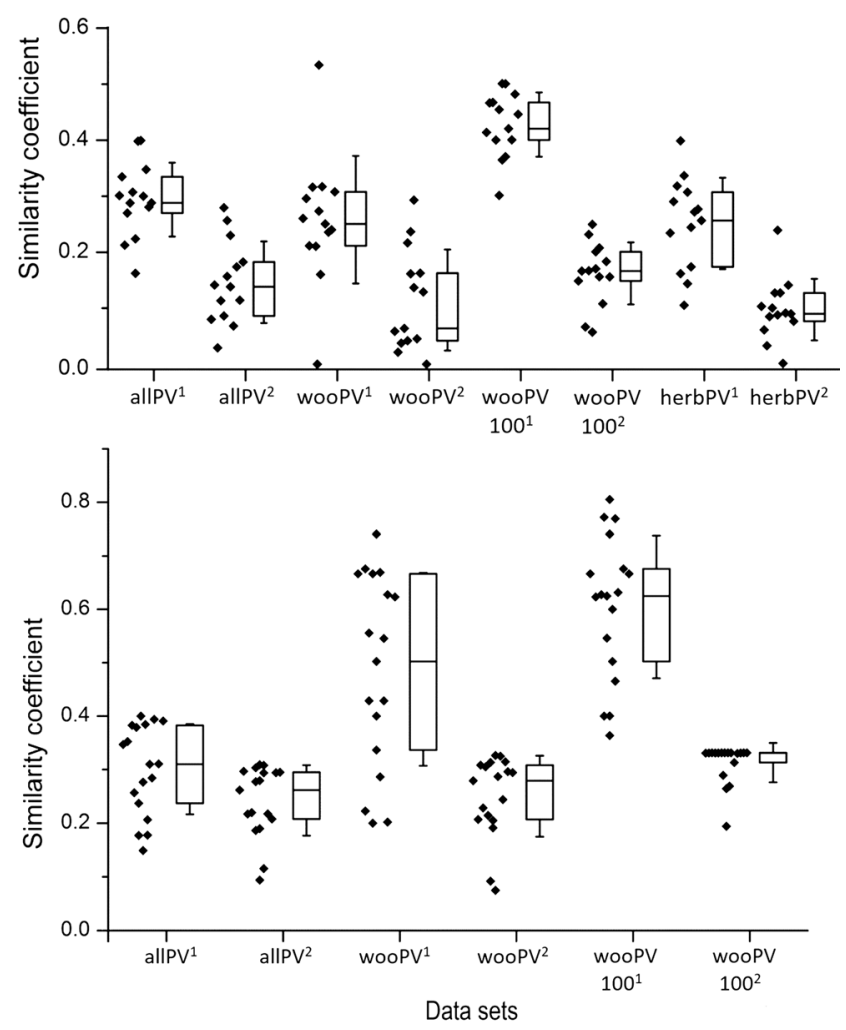

Fig. 3 Box and whiskers plots of the Bray-Curtis similarity coefficients between the vegetation plots and their corresponding pollen assemblages, and for different data sets. Upper diagram, Pieria; lower diagram, Ciomadul. Boxes represent the 25th and 75th percentiles and whiskers (lines) one standard deviation. Diamonds show the similarity values of the plots for each data set. allPV, $10 \mathrm{~m}$ total component; wooPV, $10 \mathrm{~m}$ wood component; wooPV-100, $100 \mathrm{~m}$ woody component; herbPV, $10 \mathrm{~m}$ herb component; $\left({ }^{1}\right)$, presence/absence data of untransformed cover values of vegetation plots; $\left({ }^{2}\right)$ pollen frequency data

the corresponding total floristic composition sets. For Pieria, the herb data sets yielded similarity values approximately equal to those of the $10 \mathrm{~m}$ woody and total component sets.

\section{Correlational patterns of diversity}

For the Pieria mountains statistically significant $(\mathrm{p} \leq 0.05)$ correlations for the comparison between pollen and vegetation diversity were found for the full untransformed datasets. Only low order diversity with q values between 0 and 1 of PTas and PEas for the whole vegetation showed statistically significant correlations (Fig. 4a). Evenness components of PTas were weakly correlated to richness component of PEas, but almost negatively to their PEas counterpart (Fig. 4a; ESM 2 App. 1). Evenness components of PTas were better correlated to richness components of PEas for the herb and the within $100 \mathrm{~m}$ woody components, but they were weakly negatively correlated to their counterpart for the latter and faintly positive to their counterpart of the former (Fig. 4c, d; ESM 2 App. 3 and 4). In most cases, the strongest correlations were found between the richness component of vegetation diversity $(\mathrm{q}=0)$ and Hill's numbers for pollen diversity.

All data sets, with the exception of the $10 \mathrm{~m}$ woody component, show a rather similar correlation pattern for the different orders of diversity. A decrease in correlation values between the corresponding pollen and vegetation data sets is observed as the order of diversity increases for the vegetation component. In the $10 \mathrm{~m}$ woody data set the strongest correlations were encountered when comparing low orders of vegetation diversity ( $q=0$ to 1$)$ with high orders of pollen diversity ( 32 to $\infty$ ).

For Ciomadul only one combination of pollen and vegetation, the $100 \mathrm{~m}$ woody data set for $\mathrm{q}=0$, yielded a statistically significant correlation (Fig. 5c; ESM 2 App. 2). In general, evenness $(q \geq 2)$ rather than richness components of woody PTas were better correlated with all orders of diversity of the corresponding 10 and $100 \mathrm{~m}$ vegetation data sets (Fig. 5b, c; ESM 2 Apps. 6 and 7). Unlike the Pieria data, a positive though weak correlation is observed between evenness components of PTas and PEas for the $100 \mathrm{~m}$ woody vegetation data set (Fig. 5b). Remarkably low correlations were recorded between the $10 \mathrm{~m}$ data sets of vegetation (with and without the herb component) and corresponding PTas for all combinations of diversity orders (Fig. 5a, b; ESM 2 Apps. 5 and 6).

\section{Similarity of gradients between vegetation plots and pollen assemblages}

For the Pieria data the first NMDS axis of the diagrams, where the woody component is included (Fig. 6a-c, right column), represents a gradient related to altitude and the transition from thermophilous broadleaved forest of Quercus and Ostrya to the forests in cooler areas of Fagus sylvatica, Abies borisii-regis and Pinus sylvestris. The second axis contributes to the discrimination of certain plots in the diagrams, but does not seem to represent a specific ecological gradient. In the diagram showing the herbaceous taxa data set from Pieria (Fig. 6d), the first axis mainly discriminates the plots sampled near Pinus sylvestris forests. The second axis, also in the case of the data set of herbaceous taxa, does not reflect a specific ecological gradient.

For Ciomadul, the first axis in the NMDS diagrams in Fig. 7 (a-c, right column) represents a transition gradient from the Abies alba-Fagus sylvatica-Picea abies mixed stands to the pure or mixed stands of the latter two taxa, $F$. sylvatica and $P$. abies. It may also represent a moisture gradient of Abies-Fagus-Picea mixed stands, indicated by higher frequency and abundance of ferns. The second 

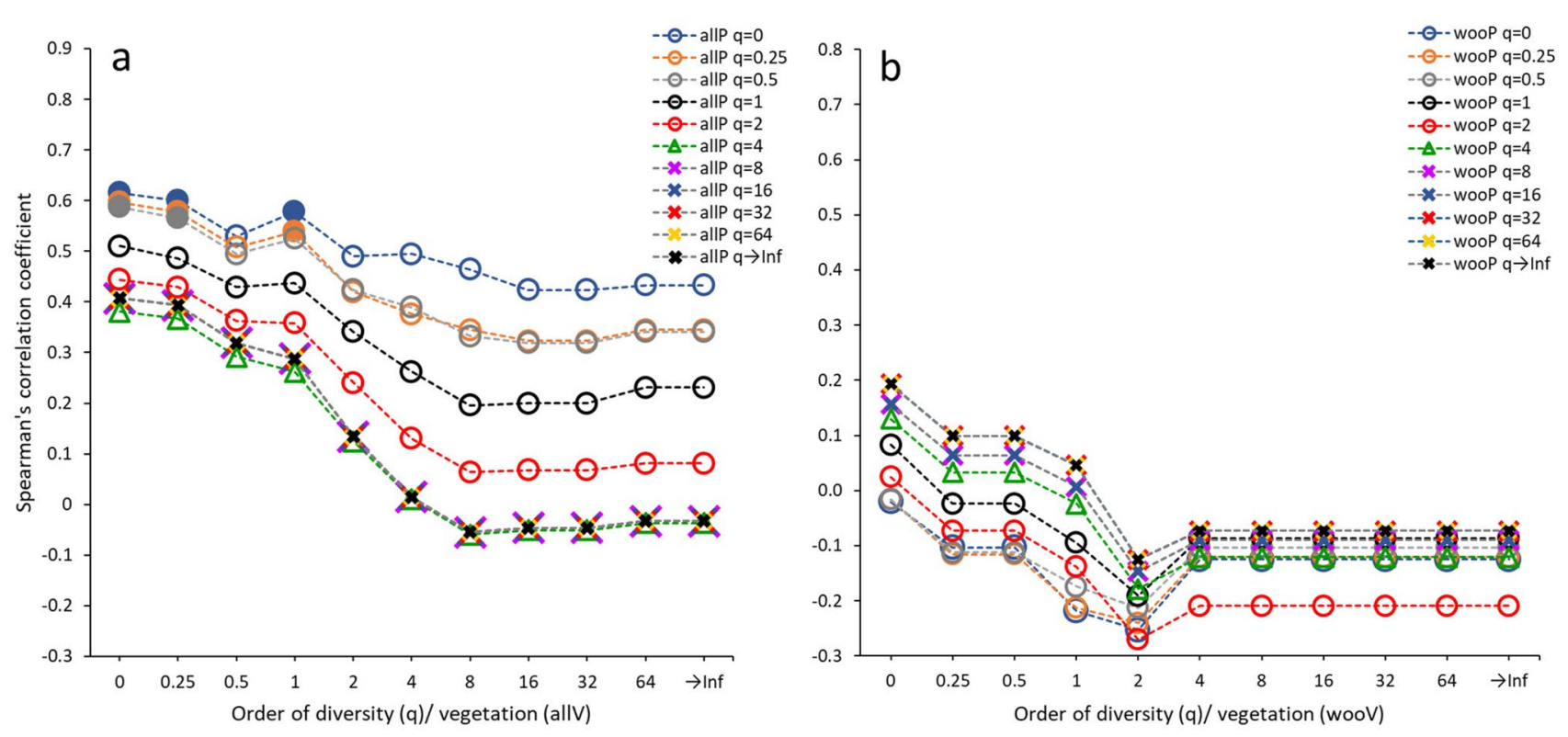

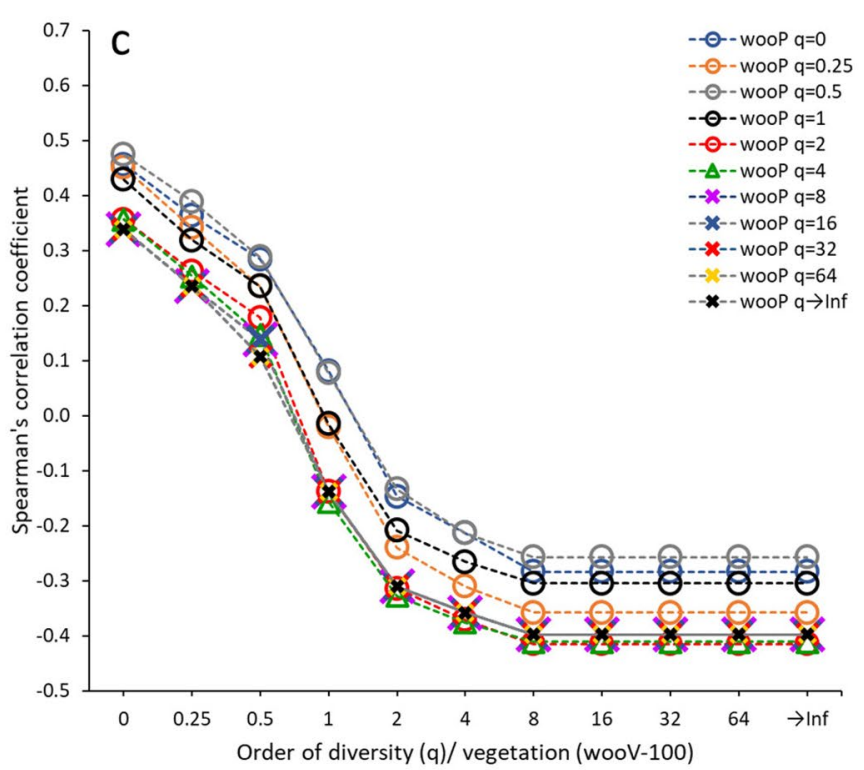

Fig. 4 Patterns of correlation coefficients between Hill's numbers of PTas and PEas for Pieria. Symbols on lines represent correlation coefficients calculated between Hill's numbers of a specific order q of PTas and Hill's numbers of the same and all other selected orders of q

NMDS axis mainly indicates the differentiation of the two Pinus sylvestris forest plots from the plots of pure or mixed Abies, Fagus and Picea stands.

The Procrustes tests indicate statistically significant correlations between all ordinations of pollen versus vegetation datasets (Table 2). For Pieria, the correlations found between the ordination diagrams were higher than those for Ciomadul. The higher resemblance between the ordination plots of PTas and PEas for the Pieria data sets in

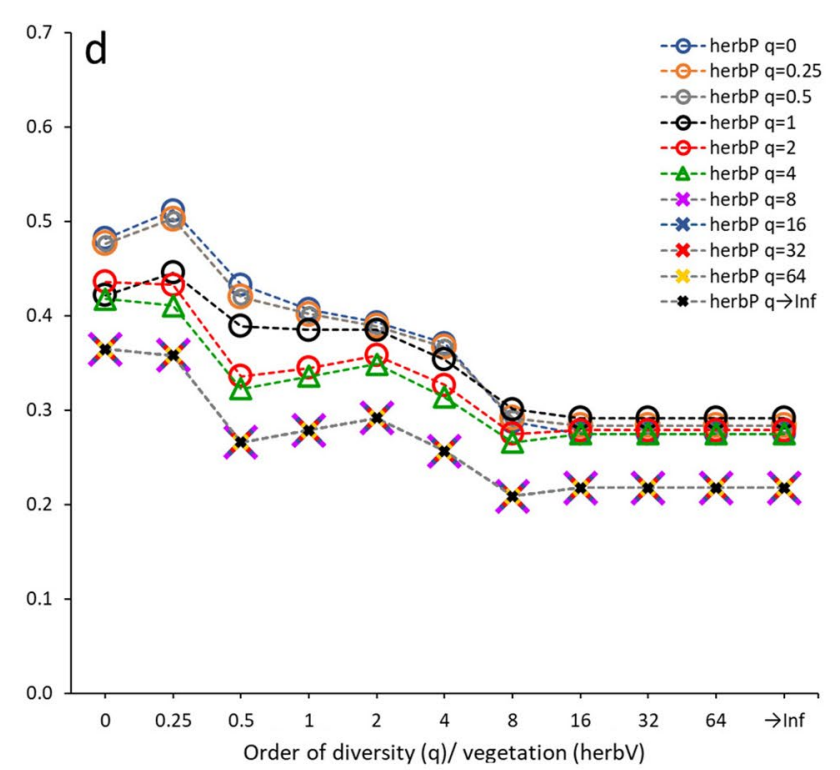

of PEas. Filled symbols indicate significant correlations. a, data set of all taxa (allPV); b, woody taxa (wooPV); c, woody taxa and vegetation plots of $100 \mathrm{~m}$ radius (wooPV-100); $\mathbf{d}$, herbaceous taxa (herbPV)

comparison with Ciomadul can be discerned already from the ordination plots (Figs. $6 \mathrm{a}-\mathrm{d}$ and $7 \mathrm{a}-\mathrm{c}$ ). The highest correlation between the Pieria data sets was found for the total floristic composition. The second highest correlation was recorded for the $100 \mathrm{~m}$ woody component. The latter data set was also the one that resulted in the highest correlation among the three data sets from Ciomadul. 

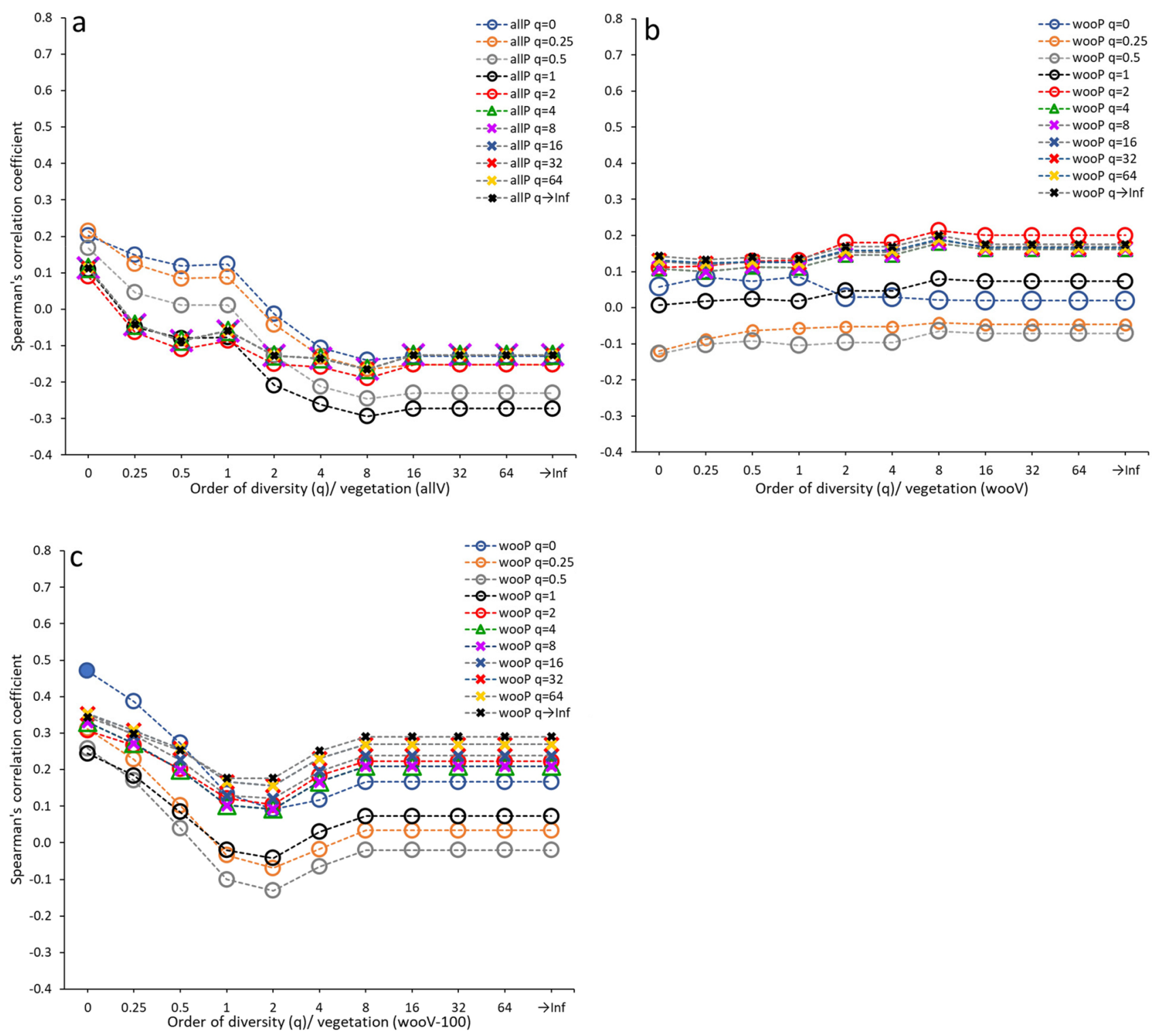

Fig. 5 Patterns of correlation coefficients between Hill's numbers of PTas and PEas for Ciomadul. Symbols on lines represent correlation coefficients calculated between Hill's numbers of a specific order q of PTas and Hill's numbers of the same and all other selected orders of

q of PEas. Filled symbols indicate significant correlations; a, data set of all taxa; b, woody taxa; $\mathbf{c}$, woody taxa and 100 m radius vegetation plots

\section{Discussion}

\section{Similarity between pollen assemblages and vegetation}

In terms of compositional similarity, a generally poor correspondence between pollen and vegetation datasets, scattering around a value of 0.3, was found (Fig. 3). Although pollen analysis is generally not regarded as a tool to evaluate presence or absence of a plant in the surrounding vegetation, the index reveals closer correspondence for presence/absence compared to abundances. This is due to the

differences between taxa in their pollen productivity and dispersal (Davis and Goodlett 1960; Andersen 1970; Prentice 1985; Schäbitz 1989). It is worth noticing that in Pieria, Fagus was poorly represented in pollen assemblages (ESM 1 Table 3), although dominant in the sampled vegetation (Tables 1,2). Very low pollen representation of Fagus has also been observed at high altitudes (Markgraf 1980) or in immature forests (Kvavadze and Stuchlik 2002) which in our case, may have been further decreased by coppicing (Waller et al. 2012). In contrast, a prolific pollen producer like Pinus, which in the Pieria mountains forms a continuous vegetation belt, dominates all pollen assemblages irrespectively 

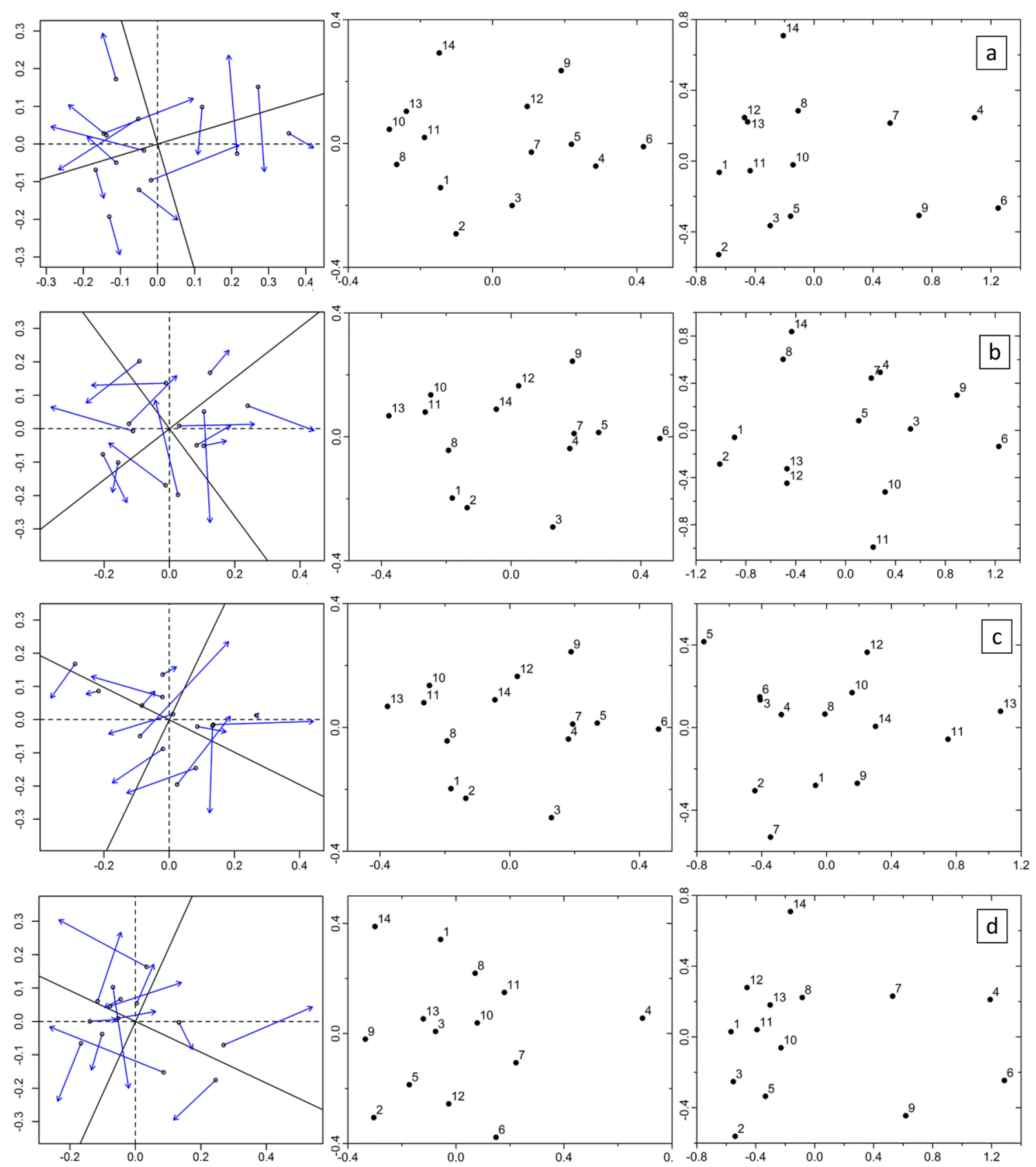

Fig. 6 Pieria; left column, plots of the Procrustes analysis errors in the first two dimensions; middle column, ordination plots of site scores along the two first axes of NMDS for the pollen assemblages; right column, vegetation plots. The rows from the top downwards correspond to the data sets of $\mathbf{a}$, the total composition (1st row); b, the $10 \mathrm{~m}$ woody component; $\mathbf{c}$, the $100 \mathrm{~m}$ woody component; $\mathbf{d}$, the herb component

taxa introduce additional large uncertainties and may not in all cases improve the relationship (Matthias et al. 2015). In both study regions, the best correspondence between pollen and vegetation was found for the presence or absence comparison of woody taxa within the $100 \mathrm{~m}$ radius. The higher similarity in Ciomadul, also for the smaller radius of $10 \mathrm{~m}$, is most probably because the pollen samples were collected from small openings in the tree canopy (ESM 1 

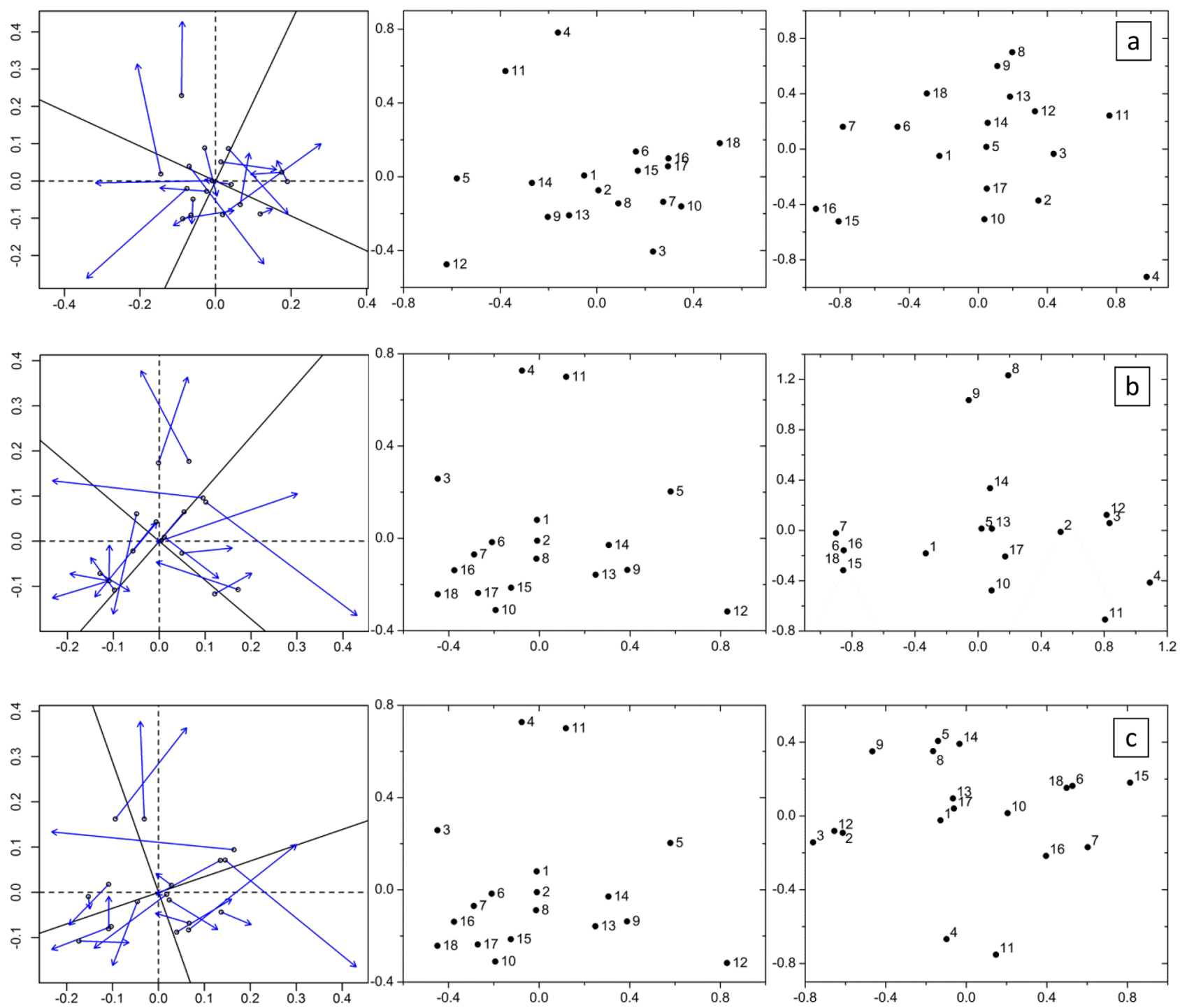

Fig. 7 Ciomadul; left column, plots of the Procrustes analysis errors in the first two dimensions; middle column, ordination plots of site scores along the two first axes of NMDS (non metric multidimensional scaling) for the pollen assemblages; right column, vegetation

plots. The rows from top to bottom correspond to the data sets of $\mathbf{a}$, the total composition; b, the $10 \mathrm{~m}$ component; c, the $100 \mathrm{~m}$ woody component

Table 2 Symmetric Procrustes residuals between configurations after optimal fit $\left(\mathrm{m}^{2}\right)$, correlations (r) between them and their significance on the basis of permutation tests for the different data sets analysed in the two study areas; NMDS ordination has been run for all the data sets

\begin{tabular}{|c|c|c|c|c|c|c|}
\hline & \multicolumn{3}{|c|}{ Pieria Mts. } & \multicolumn{3}{|c|}{ Ciomadul } \\
\hline & $\mathrm{m}^{2}$ & $\mathrm{r}$ & $\mathrm{p}$ & $\mathrm{m}^{2}$ & $\mathrm{r}$ & $\mathrm{p}$ \\
\hline allPV & 0.4858 & 0.7171 & 0.001 & 0.7396 & 0.5102 & 0.018 \\
\hline wooPV & 0.6096 & 0.6248 & 0.008 & 0.705 & 0.5432 & 0.006 \\
\hline wooPV-100 & 0.5991 & 0.6331 & 0.001 & 0.686 & 0.5603 & 0.005 \\
\hline herbPV & 0.6392 & 0.6006 & 0.007 & & & \\
\hline
\end{tabular}

Table 4)-hollows in the sense of Calcote (1995)—in a region characterised by a smaller pool of woody taxa and a regional component (mainly from plantations) is essentially absent from the pollen assemblages (Feurdean et al. 2013). The percentage of woody taxa present as pollen but absent from the vegetation is much higher for Pieria at $64.5 \%$ 
(20/31) compared to $26.7 \%$ (4/15) in Ciomadul. The relatively good correspondence between pollen and vegetation for the woody taxa in Ciomadul is much reduced when herbaceous pollen is added, due to the large representation bias of herb equivalents in pollen assemblages. We did not make an explicit comparison of the herbaceous taxa for Ciomadul because several moss samples yielded remarkably low herb pollen counts (ESM 1 Table 4), which may be due to Fagus and Picea pollen swamping these samples in below-canopy situations (compare Matthias et al. 2012).

\section{Similarity of diversity patterns between pollen assemblages and vegetation}

Comparing the two regions, there is a strong overall relationship between the floristic richness and the number of pollen types standardized to the lowest pollen sum, with 264 plant taxa and 102 pollen and spore types from Pieria versus 134 plants and 82 pollen and spore types from Ciomadul. The richness and evenness relationships of samples within either region are either not very strong or non-existent. The strongest relationship was found in Pieria for herb and total floristic and palynological richness within $10 \mathrm{~m}$ of the sample site. Here the local herbaceous flora richness seems to determine total palynological richness if we consider that the ratio of herbaceous taxa present in both PTas and PEas is much higher than that of the woody taxa. When the herbaceous vegetation is singled out, the relationship is weaker and not significant, using Spearman's rank correlation coefficient (Fig. 4b, ESM 2 App. 2,), as at least two thirds of the woody pollen types are not present in the vegetation within the 10 $\mathrm{m}$ radius. The overall low presence/absence but mostly abundance similarities for the herb dataset indicate poor correspondence between pollen types and equivalents for the taxa found in both pollen and vegetation. Indeed, only eight out of 39 taxa for which both pollen and plant were recorded are well represented in both sets, namely Crepis, Filipendula, Juncaceae, Matricaria, Potentilla, Ranunculus acris, Sanguisorba minor and Trifolium repens. Thus, although there is a correlation between palynological and floristic richness for the herbaceous types, this is weakly connected to the local vegetation. The reason for this mismatch is likely the sampling of different canopy openings, which sometimes covered the entire ground surface (100 m radius) of the sampled vegetation (ESM 1 Tables 1,2). Large openings support a rich herbaceous flora and reduce the size of the gravity component from the nearest trees which swamp the sample with their pollen, as discussed above. Therefore, in addition to the component of the local flora, a larger number of pollen types from the long-distance component are found in these samples at a standard pollen count. Moreover, a thorough vegetation sampling around moss cushions (Shaw and Whyte 2020) indicated that for several pollen taxa the relevant source area of pollen may be larger than the $10 \mathrm{~m}$ circle adopted in this study. In the case of Pieria, such vegetation sampling, on the entire surface of the $10 \mathrm{~m}$ radius, would have been extremely difficult to do. Meltsov et al. (2011) found higher palynological richness in surface sediment samples from lakes in more open environments, which, although on a different scale, agrees with this interpretation. Woody equivalents and pollen types within the $100 \mathrm{~m}$ radius show the strongest correlation for richness $(q=0)$, as also shown in other studies (Meltsov et al. 2011; Felde et al. 2016; Reitalu et al. 2019). Trees are generally prolific pollen producers, so that the pollen types of common trees will be found in all samples regardless of whether the parent tree grows in the close surroundings. This correlation is most likely due to the occurrence of rare woody taxa in the sample plots and their good correspondence in the pollen samples as seen particularly for Ciomadul (ESM 1 Tables 5, 6), where richness correlation was found to be significant. In a similar study, in terms of pollen and vegetation sampling, Blaus et al. (2020) found no significant or high correlation between pollen and woody vegetation richness, attributing this result partly to the small area sampled. Furthermore, the Ciomadul data also show a relationship between the richness of woody taxa in the vegetation plots and a stronger contribution of the evenness component in the pollen type diversity $(q>1)$. This positive correlation, though not statistically significant, indicates a positive relationship between the richness of high pollen producing plants near a sample site and the evenness of pollen abundances as pointed out by Odgaard (2001). Also, Matthias et al. (2015) found that pollen type evenness rather than richness is most strongly correlated with the richness of vegetation types within $1 \mathrm{~km}$ of a lake.

The vegetation sampling for this study used a standardized protocol for studies aiming at a comparison between pollen and vegetation (Bunting et al. 2013). This differs from other investigations aiming to compare floristic and palynological diversity (Meltsov et al. 2011; Felde et al. 2014). In the case of Pieria, it would have been beneficial for the comparison to work with floristic diversity of a wider area and although tree stands were also mapped for the $100 \mathrm{~m}$ radius, a separate floristic survey was not done. For Ciomadul, however, the large bias in the representation of herb equivalents in pollen assemblages indicates that further sampling was unnecessary. Another problem when comparing herbaceous vegetation types with pollen is that this component may change drastically between years. At Pieria we addressed this problem by collecting the moss samples at the end of the flowering season, while recording the flora during the flowering season. However, this was not possible for Ciomadul and may have some influence on the results. In terms of woody taxa, most pollen samples from Ciomadul were collected in forest hollows for which RSAP (relevant source area of pollen) is confined within 50-100 m 
(Calcote 1995). For Pieria, the RSAP for most of the pollen samples is considerably larger, at 300-400 m (Mazier et al. 2008), still we feel that even at this scale of sampling, representation of woody taxa would have shown the mismatches derived from pollen production biases and the fact that a considerable number of wind pollinated woody taxa would grow outside the sampling area.

\section{Gradient similarities between pollen assemblages and vegetation}

The significantly correlated ordinations of corresponding PEa and PTa sets in this study show the ability of pollen assemblages to reflect vegetation composition (Blaus et al. 2020) and the ecological gradients existing in vegetation as also shown by other studies (Hjelle 1999; Felde et al. 2014). Ecological gradients in vegetation plots are the outcome of differences in commonality of local plant equivalents, while gradients in pollen assemblages are much influenced by differences in commonality of extra-local/regional pollen types and differences in pollen production of woody taxa. This is especially the case for Pieria, where a large number of woody pollen types originate from outside the sampled areas and are found in nearly all pollen assemblages, such as Quercus ilex-type, Platanus, Corylus, Olea and Juglans, which coupled with biases in pollen production for major woody taxa caused in many cases no great similarity or correlation of diversity between PTas and PEas. We tested this idea by deleting taxa from PTas not recorded in vegetation plots (data not presented here) and found a reduction of PROTEST correlations between the ordinations of PTas and PEas.

\section{Conclusion}

Our results add to the still small number of studies investigating the relationship between palynological and floristic diversity, showing that this relationship is complex within regions. At terrestrial pollen sums between 500 and 600 grains, the correspondences between presence or absence of taxa in the pollen assemblage compared with the vegetation were stronger than abundance relationships. Palynological richness, rather than pollen type diversity or evenness, responded most strongly to vegetation richness and diversity. The size of the canopy opening may have determined the local floristic diversity and enhanced the importance of regional pollen type richness, thus causing a correlation between the two components in Pieria. Comparing the floristic and pollen composition shows at best a weak direct correspondence for the herbaceous taxa in Pieria, but a strong correspondence for the woody taxa in Ciomadul. These differences in the results between the two study areas indicate the influence of landscape heterogeneity, canopy openness and vegetation structure, which should be kept constant to ensure comparability.

Supplementary Information The online version contains supplementary material available at https://doi.org/10.1007/s00334-021-00831-4.

Acknowledgements We are grateful to the Vinca Minor Association (https://vincaminor.ro/ujvinca/rolunk/) and the Pro St Anne Association (http://www.szentanna-to.ro/hu/Turisztikai-egyesulet-Lazaresti/ Pro-Szent-Anna-Egyesulet-u26027.html) for granting permission and fieldwork assistance in Ciomadul. Research in the Pieria mountains (Greece) was funded by Greek State Research scholarships and the German Society for Academic Exchanges (IKYDA 174/2011-2012). Research in Ciomadul and Licence cost to publish Open Access were a part of CRC 806 "Our way to Europe" funded by the Deutsche Forschungsgemeinschaft.

Open Access This article is licensed under a Creative Commons Attribution 4.0 International License, which permits use, sharing, adaptation, distribution and reproduction in any medium or format, as long as you give appropriate credit to the original author(s) and the source, provide a link to the Creative Commons licence, and indicate if changes were made. The images or other third party material in this article are included in the article's Creative Commons licence, unless indicated otherwise in a credit line to the material. If material is not included in the article's Creative Commons licence and your intended use is not permitted by statutory regulation or exceeds the permitted use, you will need to obtain permission directly from the copyright holder. To view a copy of this licence, visit http://creativecommons.org/licenses/by/4.0/.

\section{References}

Andersen ST (1970) The relative pollen productivity and pollen representation of north European trees, and correction factors for tree pollen spectra determined by surface pollen analyses from forests. Dan Geol Unders, Ser II 96:1-99

Berglund BE, Gaillard M-J, Björkman L, Persson T (2008) Long-term changes in floristic diversity in southern Sweden: palynological richness, vegetation dynamics and land-use. Veget Hist Archaeobot 17:573-583. https://doi.org/10.1007/s00334-007-0094-x

Beug H-J (2004) Leitfaden der Pollenbestimmung für Mitteleuropa und angrenzende Gebiete. Pfeil, München

Birks HJB, Birks HH (1980) Quaternary palaeoecology. Edward Arnold, London

Birks HJB, Line JM (1992) The use of rarefaction analysis for estimating palynological richness from Quaternary pollen-analytical data. Holocene 2:1-10

Birks HJB, Felde VA, Bjune AE, Grytnes J-A, Seppä H, Giesecke T (2016) Does pollen-assemblage richness reflect floristic richness? A review of recent developments and future challenges. Rev Palaeobot Palynol 218:1-25

Blaus A, Reitalu T, Gerhold P, Hiiesalu I, Massante JC, Veski S (2020) Modern pollen-plant diversity relationships inform palaeoecological reconstructions of functional and phylogenetic diversity in calcareous fens. Front Ecol Evol 8:207. https://doi.org/10.3389/ fevo.2020.00207

Bunting MJ (2003) Pollen-vegetation relationships in non-arboreal moorland taxa. Rev Palaeobot Palynol 125:285-298 
Bunting MJ, Farrell M, Broström A et al (2013) Palynological perspectives on vegetation survey: a critical step for model-based reconstruction of Quaternary land cover. Quat Sci Rev 82:41-55

Calcote R (1995) Pollen source area and pollen productivity: evidence from forest hollows. J Ecol 83:591-602

Chao A, Gotelli NJ, Hsieh TC, Sander EL, Ma KH, Colwell RK, Ellison AM (2014) Rarefaction and extrapolation with Hill numbers: a framework for sampling and estimation in species diversity studies. Ecol Monogr 84:45-67

Chester PI, Raine JI (2001) Pollen and spore keys for Quaternary deposits in the northern Pindos Mountains, Greece. Grana 40:299-387

Coldea G (1991) Prodrome des associations végétales des Carpates du sud-est (Carpates roumanies). Doc Phytosociol 13:317-539

Colombaroli D, Tinner W (2013) Determining the long-term changes in biodiversity and provisioning services along a transect from central Europe to the Mediterranean. Holocene 23:1,625-1,634

Davis MB, Goodlett JC (1960) Comparison of the present vegetation with pollen-spectra in surface samples from Brownington Pond, Vermont. Ecology 41:346-357

Ellison AM (2010) Partitioning diversity. Ecology 91:1,962-1,963

Fall PL (2012) Modern vegetation, pollen and climate relationships on the Mediterranean island of Cyprus. Rev Palaeobot Palynol 185:79-92

Felde VA, Peglar SM, Bjune AE, Grytnes J-A, Birks HJB (2014) The relationship between vegetation composition, vegetation zones and modern pollen assemblages in Setesdal, southern Norway. Holocene 24:985-1,001

Felde VA, Peglar SM, Bjune AE, Grytnes J-A, Birks HJB (2016) Modern pollen-plant richness and diversity relationships exist along a vegetational gradient in southern Norway. Holocene 26:163-175

Feurdean A, Parr CL, Tanţău I, Fărcas S, Marinova E, Perşoiu I (2013) Biodiversity variability across elevations in the Carpathians: parallel change with landscape openness and land use. Holocene 23:869-881

Gerasimidis A, Panajiotidis S (2010) Contributions to the European Pollen Database 9. Flambouro, Pieria Mountains (northern Greece). Grana 49:76-78

Gerasimidis A, Panajiotidis S, Hicks S, Athanasiadis N (2006) An eight-year record of pollen deposition in the Pieria Mountains (N. Greece) and its significance in interpreting fossil pollen assemblages. Rev Palaeobot Palynol 141:231-243

Giesecke T, Ammann B, Brande A (2014) Palynological richness and evenness: insights from the taxa accumulation curve. Veget Hist Archaeobot 23:217-228. https://doi.org/10.1007/ s00334-014-0435-5

Giesecke T, Wolters S, van Leeuwen JFN, van der Knaap PWO, Leydet M, Brewer S (2019) Postglacial change of the floristic diversity gradient in Europe. Nat Commun 10:5422

Gotelli NJ, Chao A (2013) Measuring and estimating species richness, species diversity, and biotic similarity from sampling data. In: Levin SA (ed) Encyclopedia of biodiversity vol 5, 2nd edn. Elsevier, Amsterdam, pp 195-211

Hicks S, Amman B, Latałowa M, Pardoe H, Tinsley H (1996) Europaean Pollen Monitoring Programme. Oulu University Press, Oulu, Project Description and Guidelines

Hill MO (1973) Diversity and evenness: a unifying notation and its consequences. Ecology 54:427-473

Hjelle KL (1997) Relationships between pollen and plants in humaninfluenced vegetation types using presence-absence data in western Norway. Rev Palaeobot Palynol 99:1-16

Hjelle KL (1999) Modern pollen assemblages from mown and grazed vegetation types in western Norway. Rev Palaeobot Palynol 107:55-81

IBM Corporation Released (2012) IBM SPSS statistics for windows, Version 21.0. IBM corporation, Armonk, NY
Jackson ST (1994) Pollen and spores in Quaternary lake sediments as sensors of vegetation composition: theoretical models and empirical evidence. In: Traverse A (ed) Sedimentation of organic particles. Cambridge University Press, Cambridge, pp 253-286

Jost L (2006) Entropy and diversity. Oikos 113:363-375

Katsavouni S, Doulgeris C, Papadimos D (eds) (2014) Time series of meteorological data spatially distributed within the four pilot sites, 3rd edn. Thermi, Greek Biotope Wetland Centre (EKBY)

Kvavadze EV, Stuchlik L (2002) Relationship between biodiversity of recent pollen spectra and vegetation of beech forests in Caucasus and Carpathian Mountains. Acta Palaeobot 42:63-92

Legendre P, Birks HJB (2012) From classical to canonical ordination. In: Birks HJB, Lotter AF, Juggins S, Smol JP (eds) Tracking environmental change using lake sediments, vol 5. Data handling and numerical techniques. Springer, Dordrecht, pp 201-248

Markgraf V (1980) Pollen dispersal in a mountain area. Grana 19:127-146

Matthias I, Nielsen AB, Giesecke T (2012) Evaluating the effect of flowering age and forest structure on pollen productivity estimates. Veget Hist Archaeobot 21:471-484. https://doi.org/10. 1007/s00334-012-0373-Z

Matthias I, Semmler MSS, Giesecke T (2015) Pollen diversity captures landscape structure and diversity. J Ecol 103:880-890

Mazier F, Broström A, Gaillard M-J, Sugita S, Vittoz P, Buttler A (2008) Pollen productivity estimates and relevant source area of pollen for selected plant taxa in a pasture woodland landscape of the Jura Mountains (Switzerland). Veget Hist Archaeobot 17:479 495. https://doi.org/10.1007/s00334-008-0143-0

Meltsov V, Poska A, Odgaard BV, Sammul M, Kull T (2011) Palynological richness and pollen sample evenness in relation to local floristic diversity in southern Estonia. Rev Palaeobot Palynol 166:344-351

Odgaard BV (1999) Fossil pollen as a record of past biodiversity. J Biogeogr 26:7-17

Odgaard BV (2001) Palaeoecological perspectives on pattern and process in plant diversity and distribution adjustments: a comment on recent developments. Divers Distrib 7:197-201

Odgaard BV (2008) Species richness of the past is elusive-evenness may not be. Terra Nostra 2:209

Oksanen J (2015) Multivariate analysis of ecological communities in $\mathrm{R}$ : vegan tutorial. http://cc.oulu.fi/ jarioksa/opetus/metodi/vegan tutor.pdf

Oksanen J, Blanchet FG, Kindt R et al (2013) Vegan: Community Ecology Package. R package version 2.0-9. http://CRAN.R-proje ct.org/package $=$ vegan

OriginLab Corporation (1991-2006) OriginPro, version 7.5 SR6. OriginLab Corporation, Northampton, MA

Peres-Neto PR, Jackson DA (2001) How well do multivariate data sets match? The advantages of a Procrustean superimposition approach over the Mantel test. Oecologia 129:169-178

Prentice IC (1985) Pollen representation, source area, and basin size: toward a unified theory of pollen analysis. Quat Res 23:76-86

R Core Team (2014) R: A Language and Environment for Statistical Computing. R Foundation for Statistical Computing, Vienna. http://www.R-project.org/

Reille M (1992) Pollen et Spores d' Europe et d' Afrique du Nord. Laboratoire de Botanique Historique et Palynologie, Marseille

Reille M (1995) Pollen et Spores d' Europe et d' Afrique du Nord. Laboratoire de Botanique Historique et Palynologie, Marseille

Reitalu T, Bjune AE, Blaus A et al (2019) Patterns of modern pollen and plant richness across northern Europe. J Ecol 107:1,662-1,677

Rull V (1987) A note on pollen counting in palaeoecology. Pollen Spores 29:471-480

Schäbitz F (1989) Untersuchungen zum aktuellen Pollenniederschlag und zur holozänen Klima- und Vegetationsentwicklung in den 
Anden Nord-Neuquéns, Argentinien. Bamberger geographische Schriften 8, Universität Bamberg, Bamberg

Shaw H, Whyte I (2020) Interpretation of the herbaceous pollen spectra in paleoecological reconstructions: a spatial extension of Indices of Association and determination of individual pollen source areas from binary data. Rev Palaeobot Palynol 279:104238

Spearman C (1904) The proof and measurement of association between two things. Am J Psychol 15:72-101

Sugita S (1994) Pollen representation of vegetation in Quarternary sediments: theory and method in patchy vegetation. $\mathrm{J}$ Ecol 82:881-897

Tanţău I, Reille M, de Beaulieu JL et al (2003) Vegetation history in the eastern Romanian Carpathians: pollen analysis of two sequences from the Mohoş crater. Veget Hist Archaeobot 12:113-125. https://doi.org/10.1007/s00334-003-0015-6

Tichý L, Holt J, Nejezchlebová M (2011) Juice, Program for management analysis and classification of ecological data, 2nd edn of the program manual. Masaryk University Brno, Czech Republic, Vegetation Science Group
Tutin TG, Heywood VH, Burges NA, Moore DM, Valentine DH, Walters SM, Webb DA (ed) $(1968,1972,1976,1980)$ Flora Europaea, Vol. 2-5. Cambridge University Press, Cambridge

Tutin TG, Burges NA, Chater AO et al (1993) Flora Europaea, Vol 1: Psilotaceae to Platanaceae, 2nd edn. Cambridge University Press, Cambridge

Van der Knaap WO (2009) Estimating pollen diversity from pollen accumulation rates: a method to assess taxonomic richness in the landscape. Holocene 19:159-16

Waller M, Grant MJ, Bunting MJ (2012) Modern pollen studies from coppiced woodlands and their implications for the detection of woodland management in Holocene pollen records. Rev Palaeobot Palynol 187:11-28

Publisher's Note Springer Nature remains neutral with regard to jurisdictional claims in published maps and institutional affiliations.

\section{Authors and Affiliations}

\section{Maria Papadopoulou ${ }^{1} \cdot$ loannis Tsiripidis ${ }^{2}\left(\mathbb{D} \cdot\right.$ Sampson Panajiotidis $^{3}\left(\mathbb{D} \cdot\right.$ Georgios Fotiadis $^{4}(\mathbb{D} \cdot$ Daniel Veres ${ }^{5}$ (D) Enikö Magyari ${ }^{6,7}$ (1) Marc Bormann ${ }^{1} \cdot$ Sonia Fontana ${ }^{8} \cdot$ Lyudmila Shumilovskikh $^{9,10}$. Konstantinos Panagiotopoulos ${ }^{11}$ (]) $\cdot$ Frank Schäbitz ${ }^{1}$ [ $\cdot$ Thomas Giesecke $^{12}$ (])}

1 Institute of Geography and Didactics, University of Cologne, Gronewaldstraße 2, 50931 Köln, Germany

2 School of Biology, Aristotle University of Thessaloniki, University Campus, 54636 Thessaloniki, Greece

3 Department of Forestry and Natural Environment, Aristotle University of Thessaloniki, PO Box 270, 54124 Thessaloniki, Greece

4 School of Plant Sciences, Agricultural University of Athens, 3 Dimokratias, 36100 Karpenisi, Greece

5 Institute of Speleology, Romanian Academy, Clinicilor 5, 400006 Cluj-Napoca, Romania

6 Department of Environmental and Landscape Geography, MTA-MTM-ELTE Research Group for Paleontology, Eötvös Loránd University, Pázmány Péter sétány 1/C, 1117 Budapest, Hungary
7 Centre for Ecological Research, GINOP Sustainable Ecosystems Group, Klebelsberg Kuno 3, 8237 Tihany, Hungary

8 Cátedra de Palinilogía, Facultad de Ciencias Naturales y Museo, UNLP, Calle 64 n³, 1900 La Plata, Argentina

9 Department of Palynology and Climate Dynamics, Georg-August-University Göttingen, Wilhelm-Weber-Straße 2a, 37073 Göttingen, Germany

10 Tomsk State University, Lenin Ave 36, 634050 Tomsk, Russia

11 Institute of Geology and Minerology, University of Cologne, Zülpicher Straße 49a, 50674 Köln, Germany

12 Department of Physical Geography, Utrecht University, PO Box 80115, 3508 TC Utrecht, The Netherlands 